JIOM Nepal, Volume 41, Number 2, August 2019, page 26-29

\title{
Risk Factors for Gall Stone Diseases in Patients Presenting to General Practice Out Patient Department in a Tertiary Care Center in Nepal
}

\author{
Ram P Neupane, Tirtha M Shrestha, Shankar Raut, Ramesh P Aacharya \\ Department of General Practice and Emergency Medicine, Maharajgunj Medical Campus, Tribhuvan University Teaching \\ Hospital, Kathmandu, Nepal
}

\section{Corresponding author:}

Ram P Neupane, MBBS, MD

Department of General Practice and Emergency Medicine, Maharajgunj Medical Campus, Tribhuvan University Teaching Hospital, Kathmandu, Nepal

Email: rpneupane53@gmail.com

Submitted: May 27, 2019

Accepted : Jul 3, 2019

\begin{abstract}
Introduction

Gallstone disease (GSD) is a major public health problem that is associated with a number of risk factors. This study aims to analyze the risk factors of GSD in patients visiting General Practice Outpatient Department of Tribhuvan Universtiy Teaching Hospital.
\end{abstract}

\section{Methods}

A case-control study of 174 participants comprising 85 cases with GSD and 89 controls without GSD, as confirmed by ultrasonography of abdomen was conducted as hospital based in outpatient department of General practice, Tribhuvan University Teaching Hospital, Kathmandu from $1^{\text {st }}$ February 2018 to $31^{\text {st }}$ January, 2019. The participants were asked questions regarding putative risk factors for development of GSD and underwent physical and ultrasonographic examination. Risk factors included were age, sex, BMI, occupation, co-morbidities e.g. diabetes mellitus, hemolytic diseases, family history of GSD, smoking status, alcohol consumption, parity if applicable and dietary history. Data analysis was done by univariate method.

\section{Results}

The mean age of the case group was 47.82 years whereas mean age for the control was 46.51 years $(p=0.355)$. $22 \%$ of cases were male and $78 \%$ were female where as in control group $29 \%$ were male $(p=0.3030)$. Majority of the participants in both group were housewife by occupation and Hindu by religion.

Mean BMI of the cases and control were $24.05 \mathrm{~kg} / \mathrm{m}^{2}$ and $21.13 \mathrm{~kg} / \mathrm{m}^{2}$ respectively. BMI was found significant for the gall stone diseases $(p=<0.001)$. Similarly, Diabetes mellitus was found significant for GSD $(p=0.001) .98 \%$ cases and $61 \%$ in control group were Non-vegetarians with significant $p$ value of 0.021 . Smoking $(p=0.005)$, Nonvegetarian diet $(p=0.021)$, family history of gall stone disease $(p<0.001)$ and parity $(p<0.001)$ were also found significant for the gall stone disease.

\section{Conclusion}

High BMI, non-vegetarian diet, family history of gall stone disease, diabetes mellitus, smoking and increased parity were associated with gall stone diseases.

Keywords: Gall stone diseases, parity, risk factors, smoking, tertiary centet

\section{INTRODUCTION}

G allstone disease (GSD) is a major public health problem in many countries and is a significant cause of morbidity in Nepal. The highest prevalence was found to be in Morang and lowest in Achham. ${ }^{1,2}$ GSD is the most common disease of the biliary system and most cases are asymptomatic. Still, GSD contributes substantially to health care costs, and its complications are sometimes life threatening.

For the prevention of developing GSD, it is important to be familiar with the complete spectrum of demographic and biological markers which may be related to development of GSD.

Depending on their composition, gallstones are often divided into three major types: cholesterol-, black pigment- and brown pigment stones. Black pigment stones are more common among patients with haemolytic diseases. Brown stones are often caused by stasis and infection in the biliary system. Important factors in the development of cholesterol stones are supersaturation of cholesterol in bile, nucleation and 
growth of crystals in the gallbladder and gallbladder dysmotility resulting in impaired emptying.

Putative risk factors for GSD analyzed in our study were gender, age, religion, occupation, body mass index (BMI), diabetes, drugs (estrogen containing), history of hemolytic diseases, family history of GSD, diet, history of abdominal surgery, smoking, alcohol consumption and parity, if applicable in female populations.

\section{METHODS}

Aim of study was to determine the association with the putative risk factors for gall stone in Nepalese population who presented to tertiary hospital. It was a case control study, done in OPD of General Practice and Emergency Medicine Department, Tribhuvan University Teaching Hospital, Nepal from February 2018 to January 2019.

All patients who were diagnosed by ultrasonography (USG) abdomen as stone in gall bladder and ready to participate in our study voluntarily were taken as case.

Almost equal numbers of patients who have no stone in gall bladder as shown by USG but presented to OPD for abdominal pain were taken as control.

Patients who were younger than twenty year were excluded from the study.

All patients fulfilling the criteria for GSD who presented to OPD were considered as cases. Questions regarding putative risk factors for GSD were asked and recorded. Height and weight of the patients were measured along with general physical examination.

Those patients who presented to OPD for abdominal pain and did not have gall stone in USG abdomen were taken as control group, then questions regarding putative risk factors for gall stone asked then patient's height by measuring metallic tape and weight by digital weighing machine were taken and physical examinations done as noted.

All data were entered in SPSS 24.0 and univariate analysis was done using Chi square test.

\section{RESULTS}

Total number of participants were 175 out of them total number of case and control were 85 and 89 respectively. Mean age of the cases was 47.8 years whereas that for the control was 46.5 years. $22 \%$ of cases were male and $78 \%$ female whereas in control group 29\% were male. However, age $(p=0.355)$ and sex $(p=0.3030)$ were not found significant for GSD.

The majority of the participants in both group were housewives and Hindu. Occupation $(p=0.4)$ as well as religion $(p=0.9$ ) were not found significant for GSD.

Mean BMI of the cases was 24.05 (2.13) whereas mean BMI of the control was 21.13. BMI was found significant for the gall stone diseases $(p=<0.001)$. Regarding the co morbidities, Diabetes mellitus was found significant for GSD ( $p=0.001) .34 \%$ cases were smoker where as $13 \%$ in control group. Likewise, $98 \%$ cases and $61 \%$ in control group were Nonvegetarians.

Family history of gall stone disease in cases and control groups were $44 \%$ and $12 \%$ respectively. Regarding the parity in female participants, $62 \%$ of female in case group had more than three children whereas Nine percent of female in control group had more than three children.

Thus, Smoking $(p=0.005)$, Non-vegetarian diet $(p=0.021)$, family history of gall stone disease $(p<0.001)$, parity $(p<0.001)$ were also found significant for the gall stone disease.

\section{DISCUSSION}

Individuals with or without USG evidence of gallstones were compared. The numbers of participants in each group was almost equal and participants were nearly all consecutively enrolled in this study. The result of this study confirm and expand upon those of previous studies investigating BMI, diabetes mellitus, family history, smoking, diet, parity etc.

In our study, most of the patients (62.4\%) with gall stones were between the age of 40-60 years of age and maximum number were female (77.6\%). However, the association between age and gallstones was not significant.

BMI was observed significant with the development of GSD. ${ }^{1}$ A number of reports suggest that the relative risk for GSD is markedly higher for the obese individuals. ${ }^{3}$ Obese individuals are exposed to higher levels of biliary secretion of cholesterol from the liver and induce precipitation of monohydrate cholesterol crystals. ${ }^{4}$

In our study, diabetes mellitus was found risk factor for the gall stone diseases. Gall stone development is associated with common metabolic disorders such as obesity, diabetes mellitus and dyslipidemia. 5,6 This idea was supported by findings in epidemiological studies. ${ }^{7}$ But the matter is controversial since other studies found no such correlation. 8,9,10 Positive family history was found significant for the development of GSD in our study. Most ${ }^{11,12,13}$ but not all studies ${ }^{14}$ show a relationship of gall stone occurrence with a family history of gall stone disease.

Other variable smoking was also observed significant. Data in the literature is conflicting as to whether smoking is predisposing or protective. It has been suggested that smokers are protected against the development of gallstones through the mechanism, which leads to a decrease in prostaglandin synthesis and mucus production in gall bladder epithelium. ${ }^{15}$ Another study by Stamper et al. came to the opposite 
Table 1. Association of different variables with gallstone disease

\begin{tabular}{|c|c|c|c|c|}
\hline & Variables & Case $(n=85)$ & Control (89) & $p$-value \\
\hline Age & $\begin{array}{l}\text { Less than or equal to } 39 \\
40-59 \\
>60\end{array}$ & $\begin{array}{l}21 \\
53 \\
11\end{array}$ & $\begin{array}{l}26 \\
53 \\
10\end{array}$ & 0.355 \\
\hline Sex & $\begin{array}{l}\text { Male } \\
\text { Female }\end{array}$ & $\begin{array}{l}19 \\
66\end{array}$ & $\begin{array}{l}26 \\
63\end{array}$ & 0.303 \\
\hline Occupation & $\begin{array}{l}\text { Home maker } \\
\text { Farmer } \\
\text { Job holder }\end{array}$ & $\begin{array}{l}55 \\
11 \\
19\end{array}$ & $\begin{array}{l}48 \\
23 \\
18\end{array}$ & 0.484 \\
\hline Religion & $\begin{array}{l}\text { Hindu } \\
\text { Buddhist }\end{array}$ & $\begin{array}{l}62 \\
23\end{array}$ & $\begin{array}{l}65 \\
24\end{array}$ & 0.989 \\
\hline BMI & $\begin{array}{l}<18.5 \\
18.5-24.9 \\
>25\end{array}$ & $\begin{array}{c}0 \\
54 \\
31\end{array}$ & $\begin{array}{c}3 \\
86 \\
0\end{array}$ & $<0.001$ \\
\hline Co-morbidities & $\begin{array}{l}\text { None } \\
\text { Diabetes } \\
\text { Diabetes+Hypertensive } \\
\text { Hypertensive } \\
\text { Parkinsonism } \\
\text { Hemoglobinopathies }\end{array}$ & $\begin{array}{l}54 \\
17 \\
4 \\
8 \\
1 \\
1\end{array}$ & $\begin{array}{c}86 \\
1 \\
0 \\
2 \\
0 \\
0\end{array}$ & 0.001 \\
\hline Personal history & $\begin{array}{l}\text { None } \\
\text { Alcohol } \\
\text { Smoking } \\
\text { Alcohol+Smoking }\end{array}$ & $\begin{array}{c}51 \\
5 \\
15 \\
14\end{array}$ & $\begin{array}{l}70 \\
7 \\
5 \\
7\end{array}$ & 0.005 \\
\hline Diet & $\begin{array}{l}\text { Vegetarian } \\
\text { Non- vegeterian }\end{array}$ & $\begin{array}{c}2 \\
83\end{array}$ & $\begin{array}{l}10 \\
79\end{array}$ & 0.021 \\
\hline Family history & $\begin{array}{l}\text { Present } \\
\text { None }\end{array}$ & $\begin{array}{l}37 \\
48\end{array}$ & $\begin{array}{l}11 \\
78\end{array}$ & $<0.001$ \\
\hline Parity & $\begin{array}{l}\text { Equal and less than } 3 \text { children } \\
4-5 \text { children } \\
>5 \text { children }\end{array}$ & $\begin{array}{c}23 \\
34 \\
9\end{array}$ & $\begin{array}{l}57 \\
6 \\
0\end{array}$ & $<0.001$ \\
\hline
\end{tabular}

conclusion when they found smoking to be an independent risk factor in women smoking heavily (>35 cigarettes/day) 16. In a large British cohort study, smoking was identified as an important risk factor for the development of GSD. ${ }^{17}$

According our study, parity ( more than three) was also shown significant for GSD. Most studies document an elevated risk associated with childbearing and parity. ${ }^{18,19,20}$

In a large Danish study Jorgensen et al showed that differences in prevalence between men and women could be explained by estrogen therapy and childbirth. ${ }^{21}$

Diet was also shown as the important factor for having GSD. Consumption of high fat foods is associated with a higher risk for gall stone disease.
Nunes and Beckingham ${ }^{22}$ observed that consumption of saturated fat is associated with GSD.

\section{CONCLUSION}

Most of the patients with gall stones were between the age of 40-60 years of age and maximum number were female. High BMI, positive family history, smoking, increased parity, diabetes, nonvegetarian diet were found as the risk factors for the development of gall stone diseases.

\section{RECOMMENDATION}

Further studies could be done in multiple centers, in a large scale including multiple putative risk factor variables for the development of GSD. 


\section{CONFLICT OF INTEREST}

None declared.

\section{REFERENCES}

1. Figueiredo JC, Haiman C, Porcel J, et al. Sex and ethnic/ racial-specific risk factors for gallbladder disease. BMC Gastroenterol. 2017;17(1):153.

2. Prevalence of Gallstone disease in Nepal: multicenter ultrasonographic study Panthi. M, Pathak Y.R, Acharya A.P, Mishra C, Jaisawal R.K. Postgraduate Medical Journal of NAMS. 2007:7:02,45-50.

3. Diehl AK. Epidemiology and natural history of gallstone disease. Gastroenterol Clin North Am. 1991;20:1-19

4. Jorgensen $T$, Jorgensen LM: Gallstones and diet in a Danish population. Scand J Gastroenterol 1989; 24:821826

5. Ruhl CE, Everhart JE. Association of diabetes, serum insulin, and C-peptide with gallbladder disease. Hepatology 2000;31:299-303.

6. Mendez-Sanchez N, Chavez-Tapia NC, Motola-Kuba D, Sanchez-Lara K, Ponciano-Rodriguez G, Baptista $\mathrm{H}$, Ramos MH, Uribe M. Metabolic syndrome as a risk factor for gallstone disease. World J Gastroenterol 2005:11:1653-7.

7. Chapman BA, Wilson IR, Frampton CM, Chisholm RJ, Stewart NR, Eagar GM, Allan RB. Prevalence of gallbladder disease in diabetes mellitus. Dig Dis Sci 1996:41:2222-8

8. Mendez-Sanchez N, Chavez-Tapia NC, Motola-Kuba D, Sanchez-Lara K, Ponciano-Rodriguez G, Baptista $\mathrm{H}$, Ramos $\mathrm{MH}$, Uribe M. Metabolic syndrome as a risk factor for gallstone disease. World J Gastroenterol 2005;11:1653-7.

9. Persson GE, Thulin AJ. Prevalence of gallstone disease in patients with diabetes mellitus. A case-control study. Eur J Surg 1991;157:579-82

10. Kono S, Shinchi K, Ikeda N, Yanai F, Imanishi K. Prevalence of gallstone disease in relation to smoking, alcohol use, obesity, and glucose tolerance: a study of self-defense officials in Japan. Am J Epidemiol 1992;136:787-94

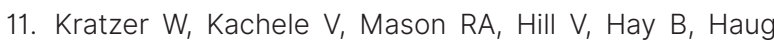
C, Adler G, Beckh K, Muche R. Gallstone prevalence in Germany: the UIm Gallbladder Stone Study. Dig Dis Sci1998;43:1285-91.

12. Chapman BA, Frampton $C M$, Wilson IR, Chisholm RJ, Allan RB, Burt MJ. Gallstone prevalence in Christchurch: risk factors and clinical significance. N Z Med J 2000;113:46-8.

13. Attili AF, De Santis A, Attili F, Roda E, Festi D, Carulli N. Prevalence of gallstone disease in first-degree relatives of patients with cholelithiasis. World J Gastroenterol 2005;11:6508-11

14. Prevalence of gallstone disease in an Italian adult female population. Rome Group for the Epidemiology and Prevention of Cholelithiasis (GREPCO). Am J Epidemiol 1984;119:796-805

15. Rhodes $M$, Venables CW. Symptomatic gallstones--a disease of non-smokers? Digestion 1991;49:221-6.

16. Stampfer MJ, Maclure KM, Colditz GA, Manson JE, Willett WC. Risk of symptomatic gallstones in women with severe obesity. Am J Clin Nutr 1992;55:652-8.

17. Murray FE, Logan RF, Hannaford PC, Kay CR. Cigarette smoking and parity as risk factors for the development of symptomatic gall bladder disease in women: results of the Royal College of General Practitioners' oral contraception study. Gut 1994;35:107-11.

18. Barbara L, Sama C, Morselli Labate AM, Taroni F, Rusticali AG, Festi D, Sapio C, RodaE, Banterle C, Puci A, et al. A population study on the prevalence of gallstone disease: the Sirmione Study. Hepatology 1987;7:913-7.

19. Diehl AK, Rosenthal M, Hazuda HP, Comeaux PJ, Stern MP. Socioeconomic status and the prevalence of clinical gallbladder disease. J Chronic Dis 1985;38:1019-26.

20. Friedman GD, Kannel WB, Dawber TR. The epidemiology of gallbladder disease: observations in the Framingham Study. J Chronic Dis 1966;19:273-92.

21. Jorgensen T. Gall stones in a Danish population: fertility period, pregnancies, and exogenous female sex hormones. Gut 1988;29:433-9.

22. Jorgensen T, Kay L, Schultz-Larsen K: The epidemiology of gallstones in a 70-year-old Danish population. Scand J Gastroenterol 1990; 25:335-340 